\title{
The Influence of Bacteriocins on Resistance
}

\author{
to Infection by Gram-Negative Bacteria
}

\author{
II. COLICIN ACTION, TRANSFER OF \\ COLICINOGENY, AND TRANSFER OF ANTIBIOTIC \\ RESISTANCE IN URINARY INFECTIONS
}

\author{
Abraham I. Braude and J. S. Siemienski \\ From the Division of Infectious Diseases, Department of Medicine, The \\ University of Pittsburgh School of Medicine, Pittsburgh, Pennsylvania 15213
}

\begin{abstract}
A в S T R A C T Dual urinary infections were produced in rats with colicinogenic Escherichia coli $\mathrm{CF} 1$, elaborating colicin $\mathrm{V}$ in the urine, and colicin-sensitive $E$. coli 9224 by injecting each organism into the medulla of opposite kidneys. The colicin-sensitive organism was eradicated from the urine of $24.3 \%$ of rats and the degree of infection by $E$. coli 9224 reduced to less than half of the control group. Colicin-resistant mutants of $E$. coli 9224 were not inhibited in mixed infections with colicin producing $E$. coli CF1. No evidence of inhibitory activity by colicin $\mathrm{V}$ was found in the kidneys. The bladder urine, but not the kidney, was also the site for transfer of colicinogeny between homologous (E. coli) and heterologous ( $E$. coli and Aerobacter aerogenes) species. Episomes controlling colicin $\mathrm{V}$ and $\mathrm{J}+\mathrm{I}$ were transferred within $24 \mathrm{hr}$ after establishing the mixed infection. Since E. coli 9224 was resistant to streptomycin and tetracycline, observations were also made on transmission of multiple drug resistance. Streptomycin and tetracycline resistance was readily transferred to $E$. coli $\mathrm{CF} 1$ within $48 \mathrm{hr}$ in the bladder. These results demonstrate that in urinary infections colicins can kill susceptible bacteria and that bacterial genetic elements are transferred.
\end{abstract}

\section{INTRODUCTION}

When coliform bacteria from the urine of patients were examined for colicin activity against the in-

Received for publication 16 August 1967 and in revised form 12 February 1968. dicator strain Escherichia coli W1985, 30\% were colicinogenic and the rate rose with the use of more indicators (1). This finding suggested that the antibiotic activity of colicins elaborated in the urinary tract might influence resistance to infection by other bacteria. In rats subjected to experimental pyelonephritis with colicinogenic bacteria, a strong and sustained colicin activity appeared in their blood and produced bactericidal activity that persisted after the normal bactericidal mechanism was inactivated by heat (2). In order to obtain more information on colicins in urinary infections, we then carried out the present study of the action of colicins on bacteria within the urinary tract. In addition to their antibiotic effects in mixed infections, we also studied the transfer of colicinogeny. The experiments were conducted with drug-resistant strains so that concurrent observations could be made on the transfer of two different types of genetic elements by bacterial conjugation in the urinary tract.

\section{METHODS}

\section{Bacteria}

A strain of $E$. coli $C F 1$, producing colicin V, was obtained from N. G. Heatley and H. W. Florey. The properties of the colicin from the organism were described in the preceding paper (1). E. coli CF1 was inhibited by $10 \mu \mathrm{g} / \mathrm{ml}$ of streptomycin or tetracycline, failed to ferment sucrose, and contained H7 flagellar antigen. These three properties were used to distinguish $E$. coli CF1 from $E$. coli 9224 in mixed urinary infections in rats. E. coli 9224, isolated from human urine, was 
killed by colicin V but was resistant to more than 100 $\mu \mathrm{g} / \mathrm{ml}$ of streptomycin or tetracycline; E. coli 9224 fermented sucrose to acid and gas, and contained $\mathrm{H}_{4}$ flagellar antigen. Both strains of $E$. coli were culturally smooth but could not be typed with $\mathrm{O}$-antiserum. The method of Fredericq (3) was used to obtain a mutant of $E$. coli 9224 that was resistant to colicin V. The colicin-sensitive $E$. coli 9224 was seeded in soft trypticase soy $(0.7 \%)$ agar over a 48 -hr agar stab culture of $E$. coli $\mathrm{CF} 1$ that had been sterilized by chloroform vapors. The colicin-resistant mutant of E. coli 9224 was selected from the zone of inhibition surrounding the killed stab culture of $E$. coli $\mathrm{CF} 1$.

Mixed urinary infections were also produced with a colicin-sensitive $\mathrm{Hfr}$ strain of $E$. coli $\mathrm{K} 12$ and the colicinogenic strains Aerobacter aerogenes 3151 or E. coli CA62. A. aerogenes 3151 , isolated from human urine, produced colicin $\mathrm{V}$; and $E$. coli $\mathrm{CA} 62$, obtained from J. Papavassiliou, produced colicin J $+\mathrm{I}$. A. aerogenes 3151 gave typical reactions for that species and was readily distinguished from $E$. coli $\mathrm{K} 12$ on eosin-methylene blue (EMB) agar (Difco Laboratories, Detroit, Mich.). The distinction between the strains of $E$. coli was based on the failure of CA62 to ferment lactose on EMB agar so that its colonies on the medium were colorless.

\section{Production of mixed urinary infections}

White male Sprague Dawley rats weighing approximately $340 \mathrm{~g}$ were obtained from Holtzman Laboratories. The two strains of bacteria used for the dual infections were always inoculated into separate parts of the urinary tract in order to prevent interactions between them within the syringe or needle.

(a) Dual urinary infections of rats with colicinogenic $E$. coli $C F 1$ and colicin-sensitive E. coli 9224. These were established by injecting each organism into the medulla of opposite kidneys. This technique, developed by Freedman and Beeson (4), invariably produced large areas of pyelonephritis extending from the renal papilla to cortex. The left kidney of 24 rats was exposed through a flank incision under ether anesthesia and an undiluted 18-hr trypticase soy broth culture of $E$. coli 9224, the colicin-sensitive strain, was inoculated into two different areas of the medulla. The volume of inoculum in each of the two medullary sites was $0.05 \mathrm{ml}$ and the injections made with $\frac{1}{4}$-inch 27 gauge needles. The incision was closed with black silk thread. $48 \mathrm{hr}$ later, after the colicin-sensitive infection was well established, the left kidney of 12 rats received the same medullary injections of colicinogenic $E$. coli $C F 1$. The remaining 12 rats were given two injections of $0.05 \mathrm{ml}$ of sterile trypticase soy broth in the right renal medulla. Bladder urine for base line culture was aspirated by means of a syringe with a 25 gauge needle through a suprapubic incision from all rats, under ether anesthesia, immediately before $E$. coli $\mathrm{CF} 1$ was injected into the right kidney. Bladder urine was aspirated for culture $48 \mathrm{hr}$ later from six rats in each group, and again from all rats 9 days after the start of the experiment when they were killed by overexposure to ether. The kidneys were removed aseptically and homogenized in a sterile Teflon tissue grinder. Controls for these experiments were established by substituting the colicinresistant mutant of $E$. coli 9224 for the colicin-sensitive parent organism. In all other respects, the control group was treated identically to the test group.

All experiments were performed three times with 24 rats each time. An additional 24 rats were used three times each in the control studies with the colicin-resistant mutant of E. coli 9224 .

(b) Dual infections with colicinogenic $A$. aerogenes $K 3151$ and colicin-sensitive $E$. coli $K 12$. The object of these experiments was to observe transfer of colicinogeny. No observations are recorded on the antibiotic action of the colicins. Two types of experiments were performed. In the first, colicin-sensitive $E$. coli $\mathrm{K} 12$ was inoculated into the right renal medulla of 24 rats. $48 \mathrm{hr}$ later colicinogenic $A$. aerogenes $\mathrm{K} 3151$ was inoculated into the opposite left renal medulla of 12 of these, and sterile trypticase soy broth into the left renal medulla of the other 12 . We performed the remainder of the experiment as described in the preceding section.

In the second type of experiment, $0.5 \mathrm{ml}$ of an $18 \mathrm{hr}$ broth culture of $E$. coli $\mathrm{K} 12$ was inoculated into the urinary bladder of 24 anesthetized rats through a midline suprapubic incision with a 27 gauge needle. Immediately afterwards, $A$. aerogenes $\mathrm{K} 3151$ was injected into the left renal medulla of 12 rats and trypticase soy broth into the left renal medulla of the remaining 12 . Urine was aspirated for culture from the bladder of four rats each at 24, 48, and $96 \mathrm{hr}$. After 1 week all rats were killed and cultures performed as in the preceding section.

(c) Dual infections with colicinogenic E. coli CA62 and colicin-sensitive $E$. coli $K 12$. These experiments were also performed to determine if colicinogeny could be transferred, and no observations are recorded on the inhibition of $E$. coli $\mathrm{K} 12$. E. coli $\mathrm{K} 12$ was inoculated into the bladder of 24 rats, $E$. coli CA62 into the left renal medulla of 12 of these, and sterile broth into the remaining 12 renal medullas. These inoculations, as well as the subsequent urine cultures, were done by the protocol used in the preceding section.

\section{Culture methods}

The homogenized kidneys and urine of rats infected with $E$. coli 9224 and $E$. coli $C F 1$ were cultured on the surface of MacConkey agar in which $1 \%$ sucrose was substituted for $1 \%$ lactose. On this medium, E. coli 9224 fermented sucrose and appeared as dark red colonies, whereas colonies of $E$. coli $C F 1$ were white because they did not ferment sucrose. Simultaneous cultures of all kidney homogenates and urines were made on MacConkeysucrose agar containing 20 or $40 \mu \mathrm{g} / \mathrm{ml}$ of streptomycin or tetracycline. E. coli $\mathrm{CF} 1$ failed to grow on this medium which contained antibiotics, but growth of $E$. coli 9224 was not inhibited. The amount of growth from a standardized loopful of kidney homogenate or $0.1 \mathrm{ml}$ of urine was graded from one to four (Fig. 1) and the infection index for a group of rats determined by the formula: sum of 


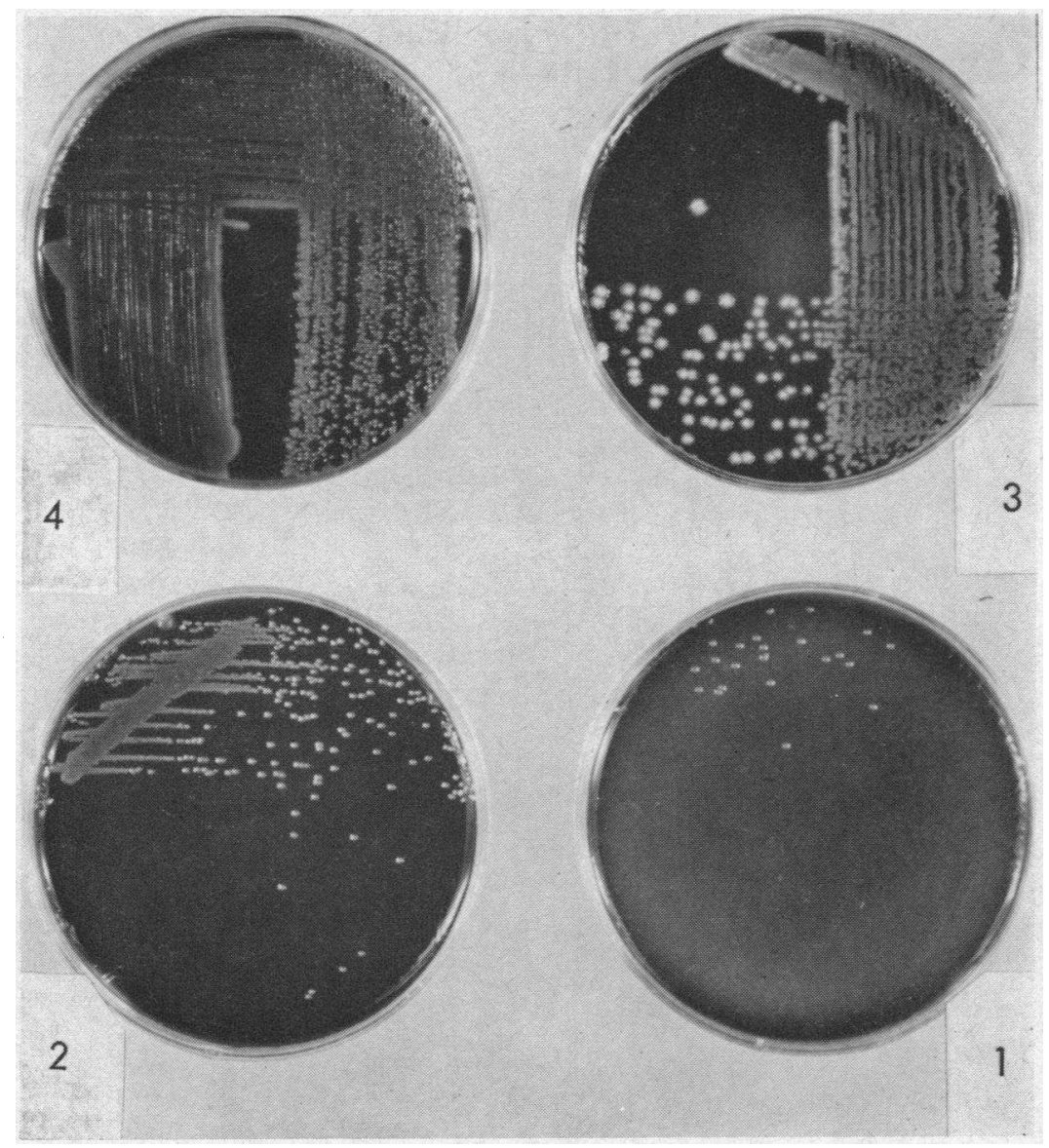

FIGURE 1 System for grading bacterial growth from kidney and urine, from 1 to 4 (intensity of infection).

grades/number of kidneys examined $\times 4$ (5). This method showed clear-cut differences that could be analyzed statistically (6). It was selected for measuring the amount of growth because neither pour-plates nor serial dilutions could be used. Pour-plates were of no value because the differentiating properties of MacConkey agar require surface growth and would be obscured by deep growth. Serial dilutions of specimens, needed for counting large bacterial populations in the kidneys of urine, could not be used in these mixed infections, because it was crucial to avoid the contact in vitro of the two organisms that would allow colicin activity or episome transfer outside of the infected animal. Serial dilution would mix the two organisms repeatedly in pipettes and test tubes. In order to avoid such contact between the two bacterial strains in vitro, it was necessary to inoculate the aspirated urine or the kidney homogenate onto the culture medium immediately. The identity of the colonies from the MacConkeysucrose media was established by fermentation of $1 \%$ sucrose broth (sucrose in phenol red broth base, Difco Laboratories), characteristic morphology, and agglutination with specific flagellar antiserum. The $\mathrm{H} 4$ and $\mathrm{H} 7$ rabbit antisera were obtained from the Communicable Dis- ease Center in Atlanta, Ga., and the agglutination test was performed by the method of Ewing and Edwards (7). In addition, the colonies were examined for production of colicin aganist $E$. coli $\mathrm{K} 12$ and for susceptibility to the colicin V produced by $E$. coli 9224 and $E$. coli CF1. Colicin production was determined by the method of Fredericq (3) described above.

The renal homogenates and urines of rats infected simultaneously with $A$. aerogenes $\mathrm{K} 3151$ and $E$. coli $\mathrm{K} 12$ were inoculated onto EMB agar and the dark-blue shiny colonies of $E$. coli were easily distinguished from the lighter mucoid colonies of $A$. aerogenes. The urines from rats with dual infections produced by $E$. coli $\mathrm{K} 12$ and $E$. coli CA62 were also inoculated onto EMB agar and differentiated by the failure of $E$. coli CA62 to ferment lactose.

\section{Evaluation of severity of pyelonephritis}

The kidneys were sectioned at the hilum so that the entire cortex, medulla, and pelvis were examined at essentially the same planes in all specimens. The kidney lesions were graded on a scale of $1-4$, according to the 


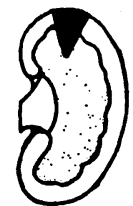

I

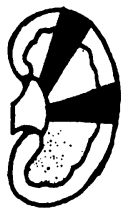

3

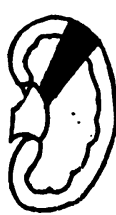

2

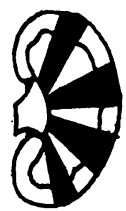

FIGURE 2 System for grading severity of pyelonephritic lesions in kidney.

severity of gross pyelonephritis changes, as shown in Fig. 2.

\section{Statistical methods}

Significance was determined by the $t$ test and by the chi-square test. $t$ was measured by the formula

$$
\frac{\bar{Y}_{1}-\bar{Y}_{2}}{\sqrt{\frac{S_{1}{ }^{2}}{N_{1}}+\frac{S_{2}{ }^{2}}{N_{2}}}}
$$

where $\bar{Y}_{1}$ and $\bar{Y}_{2}$ and $S_{1}{ }^{2}$ and $S_{2}{ }^{2}$ are the respective means and variances of $\mathrm{N}_{1}$ and $\mathrm{N}_{2}$ individuals (8).

\section{RESULTS}

Inhibition of colicin-sensitive bacteria. There was a sharp reduction in the number of colicinsensitive $E$. coli 9224 cultured from the urine of rats infected with colicinogenic $E$. coli CF1. These results are presented in detail in Tables I and II and summarized in Table III. The colicin-sensitive organism was eradicated from the bladder urine of 12 of 35 rats $(34.3 \%)$ and the infection index reduced to less than half of the control group. Colicin-resistant mutants of $E$. coli 9224 , on the other hand, were not inhibited in mixed infections with colicin producing $E$. coli $C F 1$. The mean infection index for $E$. coli $\mathrm{CF} 1$ in the urines with the colicin-sensitive $E$. coli 9224 was 3.6 ; in those with colicin-resistant $E$. coli 9224 the infection index for $E$. coli $\mathrm{CF} 1$ was 3.84 . These indices are not significantly different, and the infection index for colicin-resistant E. coli 9224 (mean 3.39, Table III) did not exceed that of E. coli CF1 in mixed infections with that organism. In other words, the uninhibited growth of the colicin- resistant mutant of $E$. coli 9224 could not be attributed to an unknown selective advantage over E. coli CF1.

In contrast to cultures of the bladder urine, cultures of the kidneys inoculated with $E$. coli 9224 did not show evidence of inhibitory activity by colicin V. The infection indices and the severity of pyelonephritis of such kidneys were the same as those from control animals whose opposite kidney was not infected with $E$. coli $\mathrm{CF} 1$. There was also no difference between the degree of infection

TABLE I

Suppression of E. coli 9924 by Colicin $V$ Elaborated by E. coli CF1 in Mixed Urinary Infections

Infection index for $E$. coli 9224 in urine

\begin{tabular}{|c|c|c|c|c|}
\hline $\begin{array}{l}\text { Exp. } \\
\text { No. }\end{array}$ & $\begin{array}{l}\text { Rat } \\
\text { No. }\end{array}$ & $\begin{array}{c}\text { Mixed } \\
\text { infections }\end{array}$ & $\begin{array}{l}\text { Rat } \\
\text { No. }\end{array}$ & $\begin{array}{c}\text { Controls } \\
\text { (E. coli } \\
9224 \text { only) }\end{array}$ \\
\hline \multirow[t]{11}{*}{1} & 1 & 0 & 12 & 3.0 \\
\hline & 2 & 0 & 13 & 4.0 \\
\hline & 3 & 3.5 & 14 & 3.0 \\
\hline & 4 & 0 & 15 & 4.0 \\
\hline & 5 & 1.0 & 16 & 1.5 \\
\hline & 6 & 3.0 & 17 & 3.0 \\
\hline & 7 & 0 & 18 & 3.0 \\
\hline & 8 & 3.0 & 19 & 2.0 \\
\hline & 9 & 0 & 20 & 3.0 \\
\hline & 10 & 4.0 & 21 & 4.0 \\
\hline & 11 & 1.5 & 22 & 3.0 \\
\hline \multirow[t]{12}{*}{2} & $1 \mathrm{~A}$ & 0 & $13 \mathrm{~A}$ & 3.5 \\
\hline & $2 \mathrm{~A}$ & 2.0 & $14 \mathrm{~A}$ & 4.0 \\
\hline & $3 \mathrm{~A}$ & 0 & $15 \mathrm{~A}$ & 3.5 \\
\hline & $4 \mathrm{~A}$ & 3.0 & $16 \mathrm{~A}$ & 4.0 \\
\hline & $5 \mathrm{~A}$ & 2.0 & $17 \mathrm{~A}$ & 3.5 \\
\hline & $6 \mathrm{~A}$ & 1.0 & $18 \mathrm{~A}$ & 4.0 \\
\hline & $7 \mathrm{~A}$ & 0 & $19 \mathrm{~A}$ & 4.0 \\
\hline & $8 \mathrm{~A}$ & 2.5 & $20 \mathrm{~A}$ & 3.0 \\
\hline & $9 \mathrm{~A}$ & 4.0 & $21 \mathrm{~A}$ & 4.5 \\
\hline & $10 \mathrm{~A}$ & 1.0 & $22 \mathrm{~A}$ & 4.0 \\
\hline & $11 \mathrm{~A}$ & 0 & $23 \mathrm{~A}$ & 3.5 \\
\hline & $12 \mathrm{~A}$ & 0 & $24 \mathrm{~A}$ & 3.0 \\
\hline \multirow[t]{12}{*}{3} & 1B & 0 & 13B & 2.5 \\
\hline & $2 \mathrm{~B}$ & 1.0 & $14 \mathrm{~B}$ & 1.0 \\
\hline & $3 B$ & 1.0 & $15 B$ & 4.0 \\
\hline & $4 B$ & 0 & 16B & 4.5 \\
\hline & $5 B$ & 3.0 & $17 \mathrm{~B}$ & 4.0 \\
\hline & $6 \mathrm{~B}$ & 3.0 & $18 \mathrm{~B}$ & 5.0 \\
\hline & $7 \mathrm{~B}$ & 4.0 & 19B & 4.5 \\
\hline & $8 B$ & 3.0 & $20 \mathrm{~B}$ & 4.0 \\
\hline & $9 B$ & 1.0 & $21 \mathrm{~B}$ & 4.5 \\
\hline & $10 \mathrm{~B}$ & 2.0 & $22 B$ & 4.0 \\
\hline & $11 \mathrm{~B}$ & 1.0 & 23B & 4.0 \\
\hline & $12 \mathrm{~B}$ & 4.0 & & \\
\hline
\end{tabular}


TABLE II

Failure of Colicin-Resistant Mutants of E. coli 9224 To Be Suppressed by Colicin V Elaborated by E. coli CF1 in Mixed Urinary Infections

Infection index for colicin-resistant $E$. coli 9224 in urine

\begin{tabular}{|c|c|c|c|c|}
\hline $\begin{array}{l}\text { Expt. } \\
\text { No. }\end{array}$ & $\begin{array}{l}\text { Rat } \\
\text { No. }\end{array}$ & $\begin{array}{c}\text { Mixed } \\
\text { infections }\end{array}$ & $\begin{array}{l}\text { Rat } \\
\text { No. }\end{array}$ & $\begin{array}{c}\text { Controls } \\
\text { (E. coli } \\
9224 \text { only) }\end{array}$ \\
\hline \multirow[t]{12}{*}{4} & R1 & 4.0 & R13 & 2.0 \\
\hline & R2 & 4.0 & R14 & 4.0 \\
\hline & R3 & 4.0 & R15 & 4.0 \\
\hline & R4 & 2.5 & R16 & 2.0 \\
\hline & R5 & 2.0 & R17 & 4.0 \\
\hline & R6 & 2.5 & R18 & 4.0 \\
\hline & R7 & 4.0 & R19 & 4.0 \\
\hline & R8 & 3.0 & R20 & 3.0 \\
\hline & R9 & 3.0 & R21 & 3.0 \\
\hline & R10 & 4.0 & R22 & 4.0 \\
\hline & R11 & 2.0 & $\mathrm{R} 23$ & 1.0 \\
\hline & R12 & 2.0 & R24 & 4.0 \\
\hline \multirow[t]{12}{*}{5} & R25 & 4.0 & R37 & 4.0 \\
\hline & R26 & 3.0 & R38 & 3.5 \\
\hline & $\mathrm{R} 27$ & 4.0 & R39 & 2.5 \\
\hline & R28 & 4.0 & $\mathrm{R} 40$ & 2.5 \\
\hline & R29 & 4.0 & R41 & 4.0 \\
\hline & R30 & 3.0 & R42 & 4.0 \\
\hline & R31 & 4.0 & R43 & 3.5 \\
\hline & R32 & 3.5 & R44 & 3.5 \\
\hline & R33 & 4.0 & R45 & 4.0 \\
\hline & R34 & 4.0 & R46 & 4.5 \\
\hline & R35 & 3.0 & R47 & 4.0 \\
\hline & R36 & 3.0 & & \\
\hline \multirow[t]{12}{*}{6} & R49 & 4.0 & R61 & 4.0 \\
\hline & R50 & 4.0 & R62 & 4.0 \\
\hline & R51 & 3.0 & R63 & 2.0 \\
\hline & R52 & 2.0 & R64 & 2.0 \\
\hline & R53 & 4.0 & R65 & 4.0 \\
\hline & R54 & 3.0 & R66 & 4.0 \\
\hline & R55 & 2.5 & R67 & 2.5 \\
\hline & R56 & 4.0 & R68 & 3.0 \\
\hline & R57 & 4.0 & R69 & 1.0 \\
\hline & R58 & 4.0 & R70 & 3.0 \\
\hline & R59 & 4.0 & R71 & 4.0 \\
\hline & R60 & 4.0 & & \\
\hline
\end{tabular}

and severity of pyelonephritis in kidneys inoculated with colicin-sensitive and colicin-resistant mutants of E. coli 9224 (Table IV).

Demonstration of colicins in bladder urine. 6 $\mathrm{ml}$ of pooled bladder urines were obtained by suprapubic aspiration from 12 rats $48 \mathrm{hr}$ after inoculating their kidneys with $0.05 \mathrm{ml}$ of an $18 \mathrm{hr}$ trypticase soy broth culture of colicinogenic $E$. coli CF1. $3 \mathrm{ml}$ of the urine pool was sterilized by addition of $0.3 \mathrm{ml}$ of chloroform and with incuba- tion for $30 \mathrm{~min}$ at room temperature. The dead bacteria were removed by centrifugation at $2000 \mathrm{~g}$ for $20 \mathrm{~min}$ and residual chloroform evaporated from the sterile supernate by heating to $37^{\circ} \mathrm{C}$ for $20 \mathrm{~min}$ in a water bath. The other $3 \mathrm{ml}$ of pooled urine was first incubated in a water bath with 1.5 $\mathrm{mg}$ of trypsin for $30 \mathrm{~min}$ at $37^{\circ} \mathrm{C}$ to destroy colicin and then treated exactly as the first $3 \mathrm{ml}$. Portions of each supernate were inoculated with an $18 \mathrm{hr}$ culture of sensitive $E$. coli 9224 in a concentration of approximately $10^{4}$ bacteria $/ \mathrm{ml}$, and compared with aliquots inoculated with an equal number of the colicin-resistant mutant of $E$. coli 9224 . The results in Table $\mathrm{V}$ show that the urines from rats infected with colicinogenic $E$. coli CF1 killed half the inoculum of $E$. coli 9224 in $3 \mathrm{hr}$, whereas the resistant mutant grew heavily. Trypsin, which has been shown to destroy colicin V (1), abolished the killing effect of the urines and no killing activity was present in urine of control rats infected with the noncolicinogenic $E$. coli $0: 113$. The experiment was repeated and the results were photographed for the picture in Fig. 3, which shows striking colicin activity in the urines of rats infected with colicinogenic bacteria. The fresh urines were processed immediately after collection, since it was found that colicin activity deteriorated when urine was allowed to stand for several days in and out of the refrigerator.

Transmission of multiple drug resistance from $E$. coli 9224 to $E$. coli CF1. Transmission of streptomycin and tetracycline resistance to $E$. coli $\mathrm{CF} 1$ was recognized by the growth of white colonies (that did not ferment sucrose) of E. coli CF1 on MacConkey-sucrose agar

TABLE III

Inhibition of $E$. coli 9224 by Colicin $V$ Elaborated in Mixed Urinary Infections*

\begin{tabular}{|c|c|c|c|c|c|}
\hline \multirow[b]{2}{*}{$\begin{array}{l}\text { Exp. } \\
\text { No. }\end{array}$} & \multirow[b]{2}{*}{$\begin{array}{c}\text { Colicin } \\
\text { sensitivity of } \\
\text { E. coli } 9224\end{array}$} & \multicolumn{2}{|c|}{$\begin{array}{l}\text { Index of infection by } \\
E . \text { coli } 9224 \text { in urine } \\
\text { (mean) }\end{array}$} & \multirow[b]{2}{*}{$\mathrm{T}$} & \multirow[b]{2}{*}{$P$} \\
\hline & & $\begin{array}{c}\text { With } \\
\text { Colicin } \\
\text { V }\end{array}$ & $\begin{array}{l}\text { Without } \\
\text { Colicin } \\
\text { V }\end{array}$ & & \\
\hline 1 & Sensitive & 1.45 & 3.04 & 3.0 & $<0.01$ \\
\hline 2 & Sensitive & 1.30 & 3.70 & 5.46 & $<0.001$ \\
\hline 3 & Sensitive & 1.75 & 3.82 & 3.66 & $<0.01$ \\
\hline 4 & Resistant & 3.1 & 3.25 & 0.38 & $>0.10$ \\
\hline 5 & Resistant & 3.63 & 3.64 & 0.03 & $>0.10$ \\
\hline 6 & Resistant & 3.46 & 3.05 & 1.07 & $>0.10$ \\
\hline
\end{tabular}

* Summary of Tables I and II. 
TABLE IV

Failure of Colicin V Elaborated by E. coli CF1 in Pyelonephritic Right Kidney to Inhibit Colicin-Sensitive E. coli 9224 in Left Kidney

\begin{tabular}{|c|c|c|c|c|c|c|c|c|c|}
\hline \multirow[b]{2}{*}{$\begin{array}{l}\text { Expt. } \\
\text { No. }\end{array}$} & \multirow[b]{2}{*}{$\begin{array}{l}\text { Colicin-sensi- } \\
\text { tivity of } E \text {. } \\
\text { coli } 9224 \text { in } \\
\text { left kidney }\end{array}$} & \multicolumn{2}{|c|}{$\begin{array}{l}\text { Infection index } \\
\text { left kidney } \\
\text { (mean) }\end{array}$} & \multirow[b]{2}{*}{$\mathrm{T}$} & \multirow[b]{2}{*}{$P$} & \multicolumn{2}{|c|}{$\begin{array}{l}\text { Index of sever- } \\
\text { ity of pyelo- } \\
\text { nephritic left } \\
\text { kidney (mean) }\end{array}$} & \multirow[b]{2}{*}{$\mathrm{T}$} & \multirow[b]{2}{*}{$P$} \\
\hline & & $\begin{array}{c}\text { Right } \\
\text { kidney } \\
\text { infected } \\
\text { with coli- } \\
\text { cinogenic } \\
\text { E. coli }\end{array}$ & $\begin{array}{c}\text { Controls } \\
\text { (right } \\
\text { kidney } \\
\text { not in- } \\
\text { fected) }\end{array}$ & & & $\begin{array}{c}\text { Right } \\
\text { kidney } \\
\text { infected } \\
\text { with coli- } \\
\text { cinogenic } \\
E . c^{f} i\end{array}$ & $\begin{array}{l}\text { Controls } \\
\text { (right } \\
\text { kidney } \\
\text { not in- } \\
\text { fected) }\end{array}$ & & \\
\hline 1 & Sensitive & 3.5 & 3.45 & 0.002 & $>0.1$ & 2.54 & 2.45 & 0.0002 & $>0.1$ \\
\hline 2 & Sensitive & 3.42 & 3.68 & 1.24 & $>0.1$ & 2.33 & 2.50 & 0.87 & $>0.1$ \\
\hline 3 & Sensitive & 3.91 & 3.71 & 1.25 & $>0.1$ & 2.58 & 2.68 & 0.37 & $>0.1$ \\
\hline 4 & Resistant & 3.71 & 3.91 & 1.05 & $>0.1$ & 2.25 & 2.62 & 1.2 & $>0.1$ \\
\hline 5 & Resistant & 3.71 & 3.82 & 0.54 & $>0.1$ & 2.83 & 2.45 & 1.2 & $>0.1$ \\
\hline 6 & Resistant & 3.66 & 3.63 & 0.112 & $>0.1$ & 2.54 & 2.72 & 0.51 & $>0.1$ \\
\hline
\end{tabular}

containing from 20 to $40 \mu \mathrm{g}$ of streptomycin or tetracycline. Numerous individual colonies were then obtained in pure cultures and identified by colonial morphology, by fermentation tests in sucrose broth, and by tube agglutination. In addition, their antibiotic resistance was confirmed by growth on MacConkey-sucrose agar containing $160 \mu \mathrm{g} / \mathrm{ml}$ of streptomycin or tetracycline. As shown in Table VI, transfer of streptomycin resistance was evident in a high percentage of bladder urines at $48 \mathrm{hr}$ and the number of strains exhibiting resistance rose slightly at 1 week. In all cases there was simultaneous transfer of both tetracycline and streptomycin resistance to each colony of $E$. coli $\mathrm{CF} 1$ acquiring drug resistance. No antibiotic resistant bacteria were isolated from the bladder urine of 18 control rats infected with E. coli $\mathrm{CF} 1$ alone.

The frequency of transfer of antibiotic resistance was determined among colonies of $E$. coli $\mathrm{CF} 1$ growing from the urine on MacConkey-sucrose agar containing no antibiotics. From each rat in which antibiotic resistance was transferred at 1 week, four colonies were picked for antibiotic sensitivity and $48 \%$ of the total from all animals were resistant to both streptomycin and tetracycline. The $\mathrm{pH}$ was measured in the urine obtained at $48 \mathrm{hr}$ from 6 rats in which antibiotic resistance was transferred. The $\mathrm{pH}$ of these urines, as determined in a Beckman $\mathrm{pH}$ meter, varied from 6.1 to 7.2, or well within the range in which bacterial conjugation is known to occur.

TABLE V

Colicin Activity in Urines from Rats with Pyelonephritis Due to Colicinogenic E. coli CF1

\begin{tabular}{|c|c|c|c|c|c|}
\hline \multirow[b]{2}{*}{ Organism producing pyelonephritis } & \multirow[b]{2}{*}{$\begin{array}{l}\text { Strain of } E . \text { coli } 9224 \\
\text { used as indicator }\end{array}$} & \multirow{2}{*}{$\begin{array}{l}\text { Trypsinization } \\
\text { of urine }\end{array}$} & \multicolumn{3}{|c|}{ No. of colonies $/ \mathrm{ml}$ of E. ccli 9224} \\
\hline & & & $0 \mathrm{hr}$ & $3 \mathrm{hr}$ & $6 \mathrm{hr}$ \\
\hline \multirow[t]{4}{*}{ E. coli $\mathrm{CF} 1$} & Colicin sensitive & No & 1,016 & 570 & 562 \\
\hline & Colicin-resistant mutant & No & 930 & 6,700 & Innumerable \\
\hline & Colicin sensitive & Yes & 1,060 & 6,800 & Innumerable \\
\hline & Colicin-resistant mutant & Yes & 900 & 10,800 & Innumerable \\
\hline \multirow[t]{2}{*}{ E. coli $0: 113$ (not colicinogenic) } & Colicin sensitive & No & 800 & 5,000 & Innumerable \\
\hline & Colicin-resistant mutant & No & 920 & 2,000 & Innumerable \\
\hline
\end{tabular}

Colicins in urines were demonstrated by their ability to kill the sensitive but not the resistant indicator strain, and by their susceptibility to tryptic digestion. Urines from control rats with noncolicinogenic renal infections did not inhibit the indicator strains. 


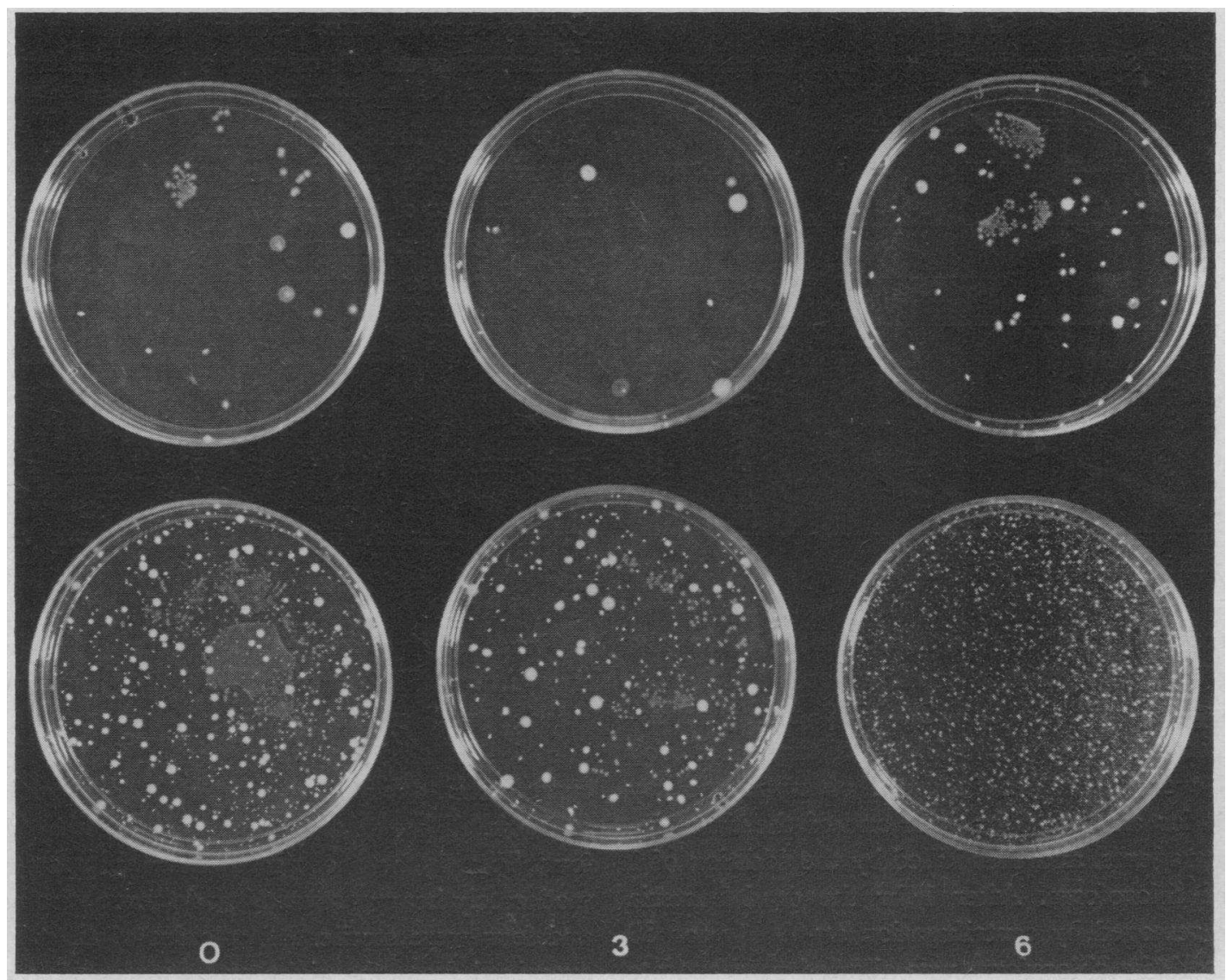

FIGURE 3 Colicin activity in infected urine. The upper row of plates shows striking antibacterial action when the colicin-sensitive $E$. coli 9224 was inoculated into urine from rats with pyelonephritis due to colicinogenic $E$. coli $\mathrm{CF} 1$. The three lower plates show increasingly heavy growth at 0,3 , and $6 \mathrm{hr}$ when portions of the same urines were inoculated with the colicin-resistant mutant of $E$. coli 9224.

Unlike the bladder, the kidney was the site of resistant colonies of $E$. coli $\mathrm{CF} 1$ in only three of the 72 rats $(4.2 \%)$. This fact indicated that the bladder urine was the medium in which drug resistance was transferred in these experiments.

Colicin resistance of $E$. coli 9224 did not significantly influence the frequency of transmission of drug resistance to $E$. coli $\mathrm{CF} 1$ in the bladder urine: 25 rats infected with the colicin-resistant mutant and 21 with the parent colicin--susceptible strain of E. coli 9224 developed antibiotic resistant colonies of $E$. coli $\mathrm{CF} 1$ in their urine after $1 \mathrm{wk}$. This difference is not significant $\left(\mathrm{chi}^{2}=0.96, P=\right.$ $>30 \%$ ) and indicates that the lethal effect of colicin does not prevent the transfer of drug resistance. This fact was also apparent from the finding that transfer of drug resistance was found at 1 wk in $50 \%$ of the rats, whose urine had been freed of the drug-resistant donor by colicin.

Drug resistance was also transferred in vitro both in broth and urine. $0.1 \mathrm{ml}$ of $E$. coli $\mathrm{CF} 1$ and $0.1 \mathrm{ml}$ of $E$. coli 9224 were inoculated into $5 \mathrm{ml}$ of trypticase soy broth, incubated at $37^{\circ} \mathrm{C}$, and subcultured at regular intervals to MacConkeysucrose agar containing $40 \mu \mathrm{g} / \mathrm{ml}$ of streptomycin. Transfer of drug resistance was noted at $3 \frac{1}{2} \mathrm{hr}$ when subcultures first produced sucrose-negative colonies of $E$. coli that grew in the presence of 40 $\mu \mathrm{g}$ of streptomycin. The same results were obtained when either colicin-sensitive or colicin-resistant cultures of $E$. coli 9224 were mixed with $E$. coli CF1. We had no success when attempting to transfer drug resistance by suspending $E$. coli $\mathrm{CF} 1$ in sterile filtrates of $E$. coli 9224 . In addition to un- 
TABLE VI

Transfer of Streptomycin and Tetracycline Resistance from E. coli 9224 To E. coli CF1 in Mixed Urinary Infection

Per cent of animals* in which antibiotic resistance was transferred

\begin{tabular}{cccc}
\hline & \multicolumn{2}{c}{ Duration of infection } \\
Exp. No. & $48 h r$ & & $1 w k$ \\
\hline 1 & 50 & 64 \\
2 & 17 & 42 \\
3 & 67 & 67 \\
4 & 67 & 75 \\
5 & 33 & 50 \\
6 & 83 & 83 \\
\hline
\end{tabular}

* 12 rats in each experiment.

treated cultures, filtrates were prepared from the drug-resistant strain after induction of lysis was attempted with $0.001 \mathrm{M} \mathrm{H}_{2} \mathrm{O}_{2}, 0.01 \%$ nitrogen mustard, and 0.1 Mitomycin C. 3-hr cultures of E. coli 9224 were incubated in $5 \mathrm{ml}$ of trypticase soy broth for another $6 \mathrm{hr}$ with one of the three inducing agents, and then killed by the addition of 1 $\mathrm{ml}$ of chloroform. After $1 \mathrm{hr}$ the dead bacteria were removed by centrifugation at $4000 \mathrm{~g}$ for 30 min and the chloroform was allowed to evaporate from the clear supernate. To $2 \mathrm{ml}$ of each supernate we added $0.2 \mathrm{ml}$ of an $18 \mathrm{hr}$ broth culture of $E$. coli $\mathrm{CF} 1$ and subcultures were made at $0,1,36$, and $80 \mathrm{hr}$ to sucrose agar containing $40 \mu \mathrm{g} / \mathrm{ml}$ of tetracycline. No antibiotic resistant colonies were isolated. These results demonstrated that contact between bacterial cells was necessary for transfer of drug resistance and that transduction by bacteriophage, as described by Novick and Morse (9) in staphylococcal infections of the rat kidney, did not occur in our experiments.

Drug resistance was transferred in rat urine in vitro by aspirating bladder urine infected only with $E$. coli $\mathrm{CF} 1$ and then, into the same syringe, urine from another rat infected only with $E$. coli 9224. These urines were taken from rats $48 \mathrm{hr}$ after bilateral pyelonephritis was produced by inoculation of either organism into the renal medullas. Four syringes containing mixtures of urine infected with both organisms were incubated at $37^{\circ} \mathrm{C}$ and subcultured after gentle agitation at regular intervals on MacConkey-sucrose agar containing $40 \mu \mathrm{g} / \mathrm{ml}$ of streptomycin as well as Mac-
Conkey-sucrose agar without streptomycin. The simultaneous culture on both plates permitted estimation of the frequency of resistance-transfer by determining the relative number of $E$. coli $\mathrm{CF} 1$ organisms that grew in the presence of streptomycin. Transfer of drug resistance was first, noted at $71 / 2 \mathrm{hr}$ when subcultures from one syringe first produced sucrose-negative colonies of $E$. coli that grew in the presence of $40 \mu \mathrm{g}$ of streptomycin. At the next subculture at $20 \mathrm{hr}$, transfer of drug resistance was found in three of four syringes. The percentage of $E$. coli $\mathrm{CF} 1$ colonies showing drug resistance was 10,4 , and 1 per cent respectively, in each of the three urine pools in which transfer occurred. The $\mathrm{pH}$ of these urines ranged from 6.5 (in the pool in which transfer failed to occur) to 7.0 .

Transfer of colicinogeny. When colicin-sensitive $E$. coli $\mathrm{K} 12$ was injected into the urinary bladder and colicinogenic $A$. aerogenes $\mathrm{K} 3151$ into the left kidney, transfer of colicinogeny occurred to $E$. coli $\mathrm{K} 12$ in eight of 12 rats examined at 1 wk. A heavy growth of E. coli $\mathrm{K} 12$ (grade four, Fig. 1) was obtained from six rat urines, moderately heavy growth (grade three) from two, and four were sterile. All colonies of E. coli $\mathrm{K} 12$ examined from the eight rats with positive urine cultures produced colicin $\mathrm{V}$, whereas the urines of all the control animals infected with $E$. coli $\mathrm{K} 12$ alone yielded only noncolicinogenic (colicin-sensitive) colonies. Transfer of colicinogeny was first noted at $24 \mathrm{hr}$ when urines from three of the rats contained colicinogenic $E$. coli $\mathrm{K} 12$. The colonies of $E$. coli $\mathrm{K} 12$ from the urine of the fourth rat, which were not colicinogenic at $24 \mathrm{hr}$, had become colicinogenic at $1 \mathrm{wk}$. In contrast to the urines, the kidneys of six of these rats yielded only noncolicinogenic colonies of $E$. coli $\mathrm{K} 12$ on culture at $1 \mathrm{wk}$, whereas those of the other six were sterile. These findings indicate that colicinogeny, like drug resistance, is transferred in the urine but not in the kidney under these experimental conditions.

Similar results were obtained when colicinogenic $E$. coli CA62, producing colicin $\mathrm{J}+\mathrm{I}$, was inoculated into the kidney of rats with bladder infections due to $E$. coli $\mathrm{K} 12$. After 1 wk all colonies of E. coli $\mathrm{K} 12$ recovered from the urine of six rats still harboring that organism in the bladder, now produced colicin $\mathrm{J}+\mathrm{I}$, and this transfer of colicinogeny was first noted at $24 \mathrm{hr}$. E. coli K12 was 
recovered from the kidney (right) of only one rat with dual infections and it was not colicinogenic. All colonies in the urines of control rats infected only with $E$. coli $\mathrm{K} 12$ remained remained noncolicinogenic.

When $A$. aerogenes $\mathrm{K} 3151$ was inoculated into the left kidney $48 \mathrm{hr}$ after $E$. coli $\mathrm{K} 12$ was introduced into the right kidney, no transfer of colicinogeny occurred. Transfer of colicinogeny failed despite the fact that the urines of all rats were heavily infected with the potential recipient strain, $E$. coli $\mathrm{K} 12$, upon introducing infection with the colicinogenic organism, and that at $1 \mathrm{wk}$ dual infections of the bladder with both organisms were present. Attempts to obtain such transfer by repeating this experiment twice gave identical results.

Transfer of colicinogeny occurred in a small number of the rats in which drug resistance was readily transferred, as described above. In these animals $E$. coli $\mathrm{CF} 1$, producing colicin $\mathrm{V}$, was inoculated into the left kidney, $48 \mathrm{hr}$ after the opposite kidney had been infected with colicinsensitive $E$. coli 9224 . In one such experiment, the urines of four of the 12 rats yielded strains of $E$. coli 9224 which produced colicin V 1 wk after the second kidney was infected, and transfer of colicinogeny was noted to have occurred already in these animals on bladder aspiration at $48 \mathrm{hr}$. When the experiment was repeated a second time, colicinogenic colonies of $E$. coli 9224 were recovered from only one rat, and no transfer of colicinogeny was noted in the third time the experiment was performed.

\section{DISCUSSION}

Although several causes of antagonism between bacteria have been proposed (10-13), colicin activity is the only possible explanation for the inhibition of $E$. coli observed in these mixed urinary infections. The proof that colicins are responsible for the antagonisms in these experiments comes from the finding that colicin-resistant mutants were not inhibited in dual infections with colicinproducing bacteria. Except for their colicin resistance these mutants resemble the colicin-sensitive parent strains in all discernible properties, including biochemical activity, antigenic structure, morphology, growth rate, antibiotic resistant, and pathogenicity for the kidney (Tables III and VII).
TABLE VII

Uniform Properties of Colicin-Sensitive and Colicin-Resistant Strains of E. coli 9224*

\begin{tabular}{lcc}
\hline & $\begin{array}{c}\text { Colicin } \\
\text { sensitive }\end{array}$ & $\begin{array}{c}\text { Colicin } \\
\text { resistant }\end{array}$ \\
\hline $\begin{array}{l}\text { Utilization of citrate as sole carbon } \\
\quad \text { source }\end{array}$ & 0 & 0 \\
$\begin{array}{l}\text { Production of acid (pH 6.10) by } \\
\quad \text { glucose fermentation }\end{array}$ & + & + \\
$\begin{array}{l}\text { Production of indol from tryptophan } \\
\text { Reduction of nitrate to nitrite }\end{array}$ & + & + \\
Fermentation of lactose, sucrose, & + & + \\
$\quad$ maltose, mannitol, and arabinose & + & + \\
$\quad$ to acid (pH 5.5) and gas & & \\
$\begin{array}{l}\text { Growth in 20 } \mu \mathrm{g} / \mathrm{ml} \text { of streptomycin } \\
\text { Production of colicin }\end{array}$ & + & + \\
Motile & 0 & 0 \\
Flagellar antigen & + & + \\
Decarboxylation of ornithine & $\mathrm{H} 4$ & $\mathrm{H} 4$ \\
Decarboxylation of lysine & + & + \\
Production of hemolysin for rabbit & + & + \\
$\quad$ erythrocytes & + & + \\
Production of catalase & & \\
\hline
\end{tabular}

* Methods are given in reference 7 .

It follows, therefore, that the difference in survival of the resistant and sensitive organisms can only be the result of the killing by colicin.

It is also clear that colicin kills in the urine and not in the kidney. Although colicin V elaborated in pyelonephritis by $E$. coli $C F 1$ reaches the bloodstream and enhances the bactericidal power of blood (2), sensitive organisms in the kidney appear to be protected from this bactericidal factor. It has also been proposed that bacteria in the kidney are also protected from the normal bactericidal system of blood (14). Two different mechanisms, however, account for the failure of the two types of circulating bactericidal systems to operate in the kidney. The normal bactericidal mechanism of blood is complement-dependent and presumably loses its effect because complement is inactivated by intrarenal $\mathrm{NH}_{3}$ (14). Colicin, on the other hand, acts independently of complement so that its failure to kill bacteria in the kidney is attributed to inadequate renal concenerations because of poor diffusion or excretion from the blood. In the urine, diffusion or excretion were no problem because colicin was being produced in the same medium in which the susceptible bacteria were growing. The concentration of colicin reached levels high enough to eradicate the colincin-sensi- 
tive strain of $E$. coli from the bladder urine in $34.3 \%$ of the rats.

The bladder urine also proved to be a suitable medium for transfer of colicinogeny. Episomes controlling both colicins $\mathrm{V}$ and $\mathrm{J}+\mathrm{I}$ were transmitted with high frequency. The genetic element controlling colicin production was transferred just as readily in the bladder between heterologous species ( $A$. aerogenes 3151 and $E$. coli $\mathrm{K} 12$ ) as homologous species ( $E$. coli $\mathrm{CA62}$ and $E$. coli $\mathrm{K} 12)$. In the heterologous dual infection, the large encapsulated colicinogenic $A$.aerogenes 3151 could be distinguished from the small nonencapsulated E. coli $\mathrm{K} 12$; thus it was easy to find in the rat urines the characteristic pairing and clumping of colicinogenic and noncolicinogenic bacteria that has been observed during transfer of colicinogeny in vitro (Fig. 4) (15). Although it is possible that the paired organisms were caught in the act of conjugation necessary for transmission of the extrachromosomal deoxyribonucleic acid (DNA) (episomal) from one cell to another (16), electron microscopic observations will be necessary to establish this phenomenon.

Further proof that genetic material could be transferred during conjugation in the bladder urine came from the finding that streptomycin and tetracycline resistance spread to sensitive cells of E. coli. Resistance was transferred faster than the donor cells were killed by the colicin of the recipient $E$. coli. The transfer was completed in urines aspirated $48 \mathrm{hr}$ after the dual infection was initiated and had probably occurred much earlier, since streptomycin resistance was detected in recipient cells a few hours after mixture of the two strains in broth cultures. Two facts emphasize that susceptibility of the drug-resistant donor to colicin did not prevent transfer of drug resistance. One is the finding that drug resistance was not transferred at a higher rate when the donor strain of $E$. coli was resistant to colicin; and the other is that transfer occurred even in rats whose bladders were eventually sterilized of the donor strain. It is possible that conditions for transfer of drug resistance are so favorable in the urinary bladder that it cannot be interrupted by agents that eventually kill the participating bacterial cells. An equally plausible alernative, however, is that the colicin-sensitive donor cells transmitted the genetic

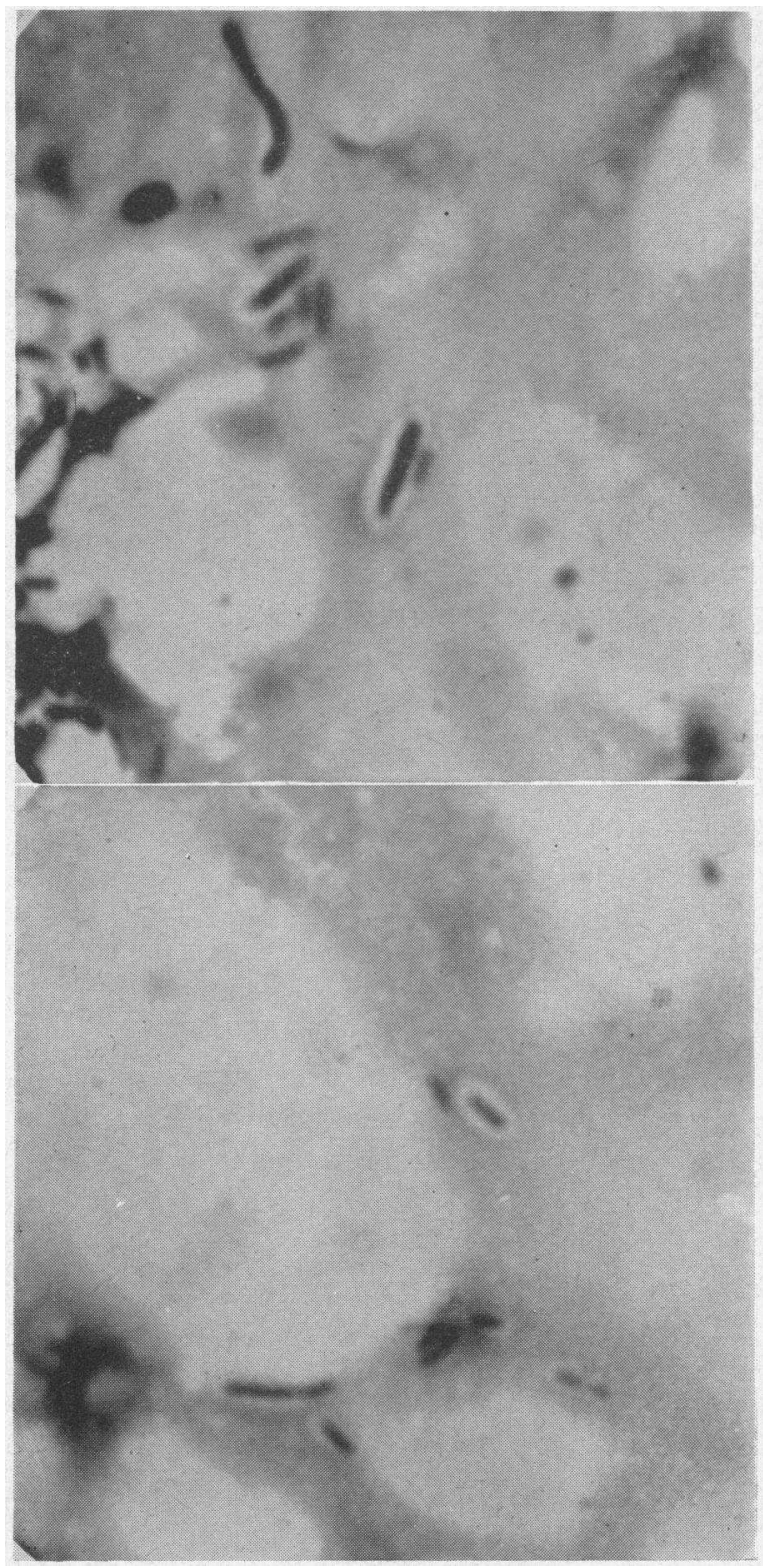

FIgURE 4 Pairing and clumping of colicinogenic $A$. areogenes 3151 (encapsulated) and $E$. coli $\mathrm{K} 12$ (no capsule). Such pairing and clumping has been observed during transfer of colicinogeny in vitro. Side-to-side and end-toend positions of the paired organisms are characteristic of conjugation.

elements controlling drug resistance to a few colicinogenic recipients, which then initiated their transfer throughout the rest of the drug-sensitive population. In either cases it can be inferred that bladder urine promotes the heavy bacterial growth and provides the energy source for the donor, 
which are prerequisites for optimal transfer of drug resistance.

If these experimental findings occur in infected human urines, they could account for certain important clinical phenomena. Bacteriocins, for example, could be one of the factors responsible for the observation that mixed urinary infections occur much less commonly than do pure infections, even though mixtures of two or more bacterial strains are undoubtedly introduced into the bladder during instrumentation and in most other circumstances which induce human urinary infection. The present study shows that the bacteriocin of one strain of Gram-negative bacteria can eliminate another strain from the bladder and thereby prevent a mixed infection. This study also provides a mechanism that can explain how eradication from the urine of one bacterial strain by treatment is sometimes followed by the appearance of another strain. This explanation depends on the finding that colicin eliminated a second organism from the bladder, but not the kidney, so that the double infection was not evident on urine culture. Removal of the colicinogenic bacteria by treatment would allow the second organism, previously sheltered in the kidney, to grow freely in the bladder.

The high rate of bacterial gene transfer found in the rat bladder undoubtedly exists in human urinary infections as well. The transfer of greatest practical significance involves the genes conferring resistance to multiple antibiotics. These genes are transferred during bacterial conjugation by the agent RTF resistance transfer factor). Transfer of multiple drug resistance within the human bowel has been demonstrated in volunteers by the isolation from their feces of Shigella organisms containing the $\mathrm{R}$ factor, composed of $\mathrm{RTF}$ and the specific genes for drug resistance (17). The $R$ factor has also been found in Enterobacteriaceae recovered from human urine (18). The present evidence indicates that an excellent opportunity for transfer of epidemic drug resistance would exist in bladders of hospitalized patients subjected to indwelling catheters or other instrumentation that predisposed to mixed infection.

\section{ACKNOWLEDGMENT}

This study was supported by U. S. Public Health Service Research grant HE 03220.

\section{REFERENCES}

1. Braude, A. I., and J. S. Siemienski. 1965. The influence of bacteriocins on resistance to infection by Gram-negative bacteria. I. The effect of colicin on bactericidal power of blood. J. Clin. Invest. 44: 849.

2. Goldsand, G., J. Siemienski, and A. I. Braude. 1967. Bacteriocins in the blood stream. Clin. Res. 15: 307.

3. Fredericq, P. 1957. Colicins. Ann. Rev. Microbiol. $11: 7$.

4. Freedman, L. R., and P. B. Beeson. 1958. Experimental pyelonephritis. IV. Observations on infections resulting from direct inoculation of bacteria into different zones of the kidney. Yale J. Biol. Med. 30: 406.

5. Braude, A. I., A. Shapiro, and J. Siemienski. 1959. Hematogenous pyelonephritis in rats. III. Relationship of bacterial species to the pathogenesis of acute pyelonephritis. J. Bacteriol. 77: 270.

6. Shapiro, A. P., A. I. Braude, and J. Siemienski. 1959. Hematogenous pyelonephritis in rats. IV. Relationship of bacterial species to the pathogenesis and sequelae of chronic pyelonephritis. J. Clin. Invest. 38: 1228.

7. Edwards, P. R., and W. H. Ewing. 1962. Identification of Enterobacteriaceae. Burgess Publishing Company, Minneapolis. 2nd edition.

8. Batson, H. C. 1956. An Introduction to Statistics in the Medical Sciences. Burgess Publishing Company, Minneapolis. 18.

9. Novick, R. P., and S. I. Morse. 1967. In vivo transmission of drug resistance factors between strains of Staphylococcus aureus. J. Exptl. Med. 125: 45.

10. Ribble, J. 1967. A mechanism of bacterial interference in vitro. J. Immunol. 98: 716.

11. Hentges, D. J. 1967. Inhibition of Shigella flexneri by the normal intestinal flora. I. Mechanisms of inhibition of Klebsiella. J. Bacteriol. 93: 1369.

12. Stolp, H., and M. P. Starr. 1963. Bdellovibrio bacteriovirus gen. et sp. n., predatory, ectoparasitic and bacteriolytic microorganism. Antonie van Leeuwenhoek. J. Microbiol. Serol. 29: 217.

13. McCabe, W. R. 1967. Bacterial interference: its effect on reticuloendothelial function in embryonated eggs. J. Clin. Invest. 46: 1093.

14. Beeson, P. B., and D. Rowley. 1959. The anticomplementary effect of kidney tissue: its association with ammonia production. J. Exptl. Med. 110: 685.

15. Smith, S. M., and B. A. D. Stocker. 1962. Colicinogeny and recombination. Brit. Med. Bull. 18: 46.

16. Gross, J. D. 1965. Transfer of genetic material during bacterial conjugation. Brit. Med. Bull. 21: 206.

17. Watanabe, T. 1963. Infective heredity of multiple drug resistance in bacteria. Bacteriol. Rev. $27: 87$.

18. Smith, D. H., and S. E. Armour. 1966. Transferable R factors in enteric bacteria causing infection of genitourinary tract. Lancet. 2: 15.

19. Jacob, F., and E. L. Wollman. 1961. Sexuality and the Genetics of Bacteria. Academic Press Inc., New York. 113. 